\title{
Effect of Variation in Different Mechanical Setting of Draft Change Pinion in Trutzschler Carding Machine for Cotton and Polyester Carded Slivers
}

\author{
Anowar Hossain ${ }^{1 *}$ and Samanta $\mathrm{AK}^{2}$ \\ ${ }^{1}$ Department of Textile Engineering, City University, Bangladesh \\ ${ }^{2}$ Department of Jute and Fiber Technology, University of Calcutta, India
}

Submission: June 06, 2019; Published: July 08, 2019

*Corresponding author: Anowar Hossain, Department of Textile Engineering, City University, Savar, Dhaka, Bangladesh

\begin{abstract}
Different engineering setting of Draft Change Pinion like 13, 15, 17, 19, 21 were studied for production of cotton carded sliver and polyester carded sliver in a specific setting of carding machine to observe the card sliver variation, card sliver evenness, card sliver neps as well as sliver irregularity considering the geometrical variation of sliver surface. Weight fluctuation of 10 different samples were studied for different engineering setting of Draft Change Pinion (DCP) like 13, 15, 17, 19, 21 and samples of DCP 17 was observed more homogeneous than other samples studied in this experiment both for cotton and polyester carded sample under observation of weight variation of 10 different carded sample. The overall weight variation in cotton and polyester sliver/6yds is considered in general as DCP-13<DCP-15<DCP- $17<$ DCP- $19<$ DCP- 21 . Cotton sliver weight in gm/6yds showed almost (4-10) \% less comparing to polyester sliver for different DCP. Setting of exact DCP may be ensured the uniform sliver which may enhance the quality of next process in spinning industries like blending of cotton and polyester sliver in draw frame /blending of cotton-cotton sliver in draw frame, roving in simplex and yarn formation in ring frame. SEM study of polyester and cotton sliver were investigated the effect of fineness for different cohesion of natural fibre as cotton and synthetic fibre as polyester and its interaction with sliver irregularity, surface variation when it was trialed with Draft Change Pinion-17. So, an optimum selection of DCP may confirm the exact orientation of fibre in carding stage which may influence the next process of spinning by ensuring the quality of finished yarn for cotton spinning and polyester-cotton blended spinning (Figures $1 \& 2$ ).
\end{abstract}

Keywords: Cotton carded sliver; Polyester carded sliver; Draft change pinion (DCP); Carding machine

\section{Introduction}

The polyester cotton blended yarn can be made well by proper processing of cotton fibres in blowroom ( picture of blowroom as figure 1 ) and thereafter ptocessed in cotton carding (picture of cotton carding machine in figure 2), on which next or subsequent spinning performance depends.

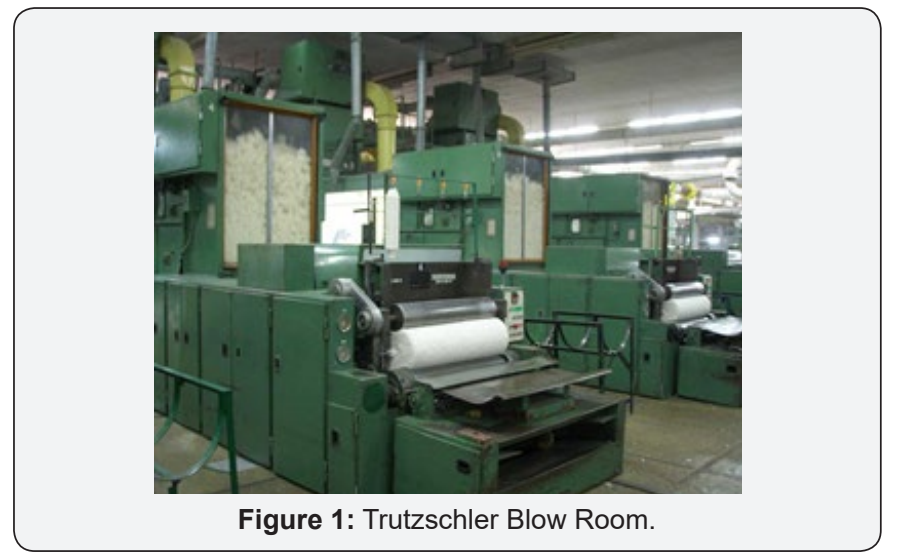

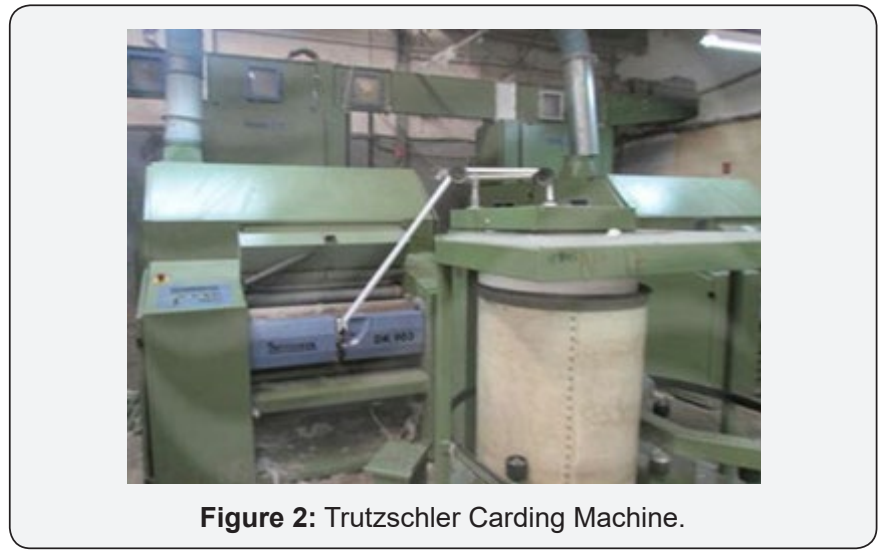

Carding is one of the most important operations in the spinning process as it directly determines the final features of the yarn, above all as far as the content of neps and husks are concerned. There are many objectives of the carding process and these can be summarized as: 
a) Opening the tufts into individual Fibres.

b) Eliminating all the impurities contained in the Fibre that were not eliminated in the previous cleaning operations.

c) Selecting the Fibres based on length, removing the shortest ones.

d) Removal of neps.

e) Parallelizing and stretching of the Fibre.

f) Transformation of the lap into a sliver, therefore into a regular mass of untwisted Fibre.

$$
\text { Draft }=\frac{\text { Draft constant }}{\text { Draft change pinion }}
$$

During carding if need to change draft, then pinion generally change. The number of teeth of this changed DCP higher than draft will be less. If the draft is lower than the production will be higher, but hank will be lower. If the no. of teeth higher but hank will be lower. If the no. of teeth of this changed DCP is lower than it happens oppositely.

$$
\operatorname{DCP}(\uparrow)-\operatorname{Draft}(\downarrow)-\operatorname{Production}(\uparrow)-\operatorname{Hank}(\downarrow)
$$
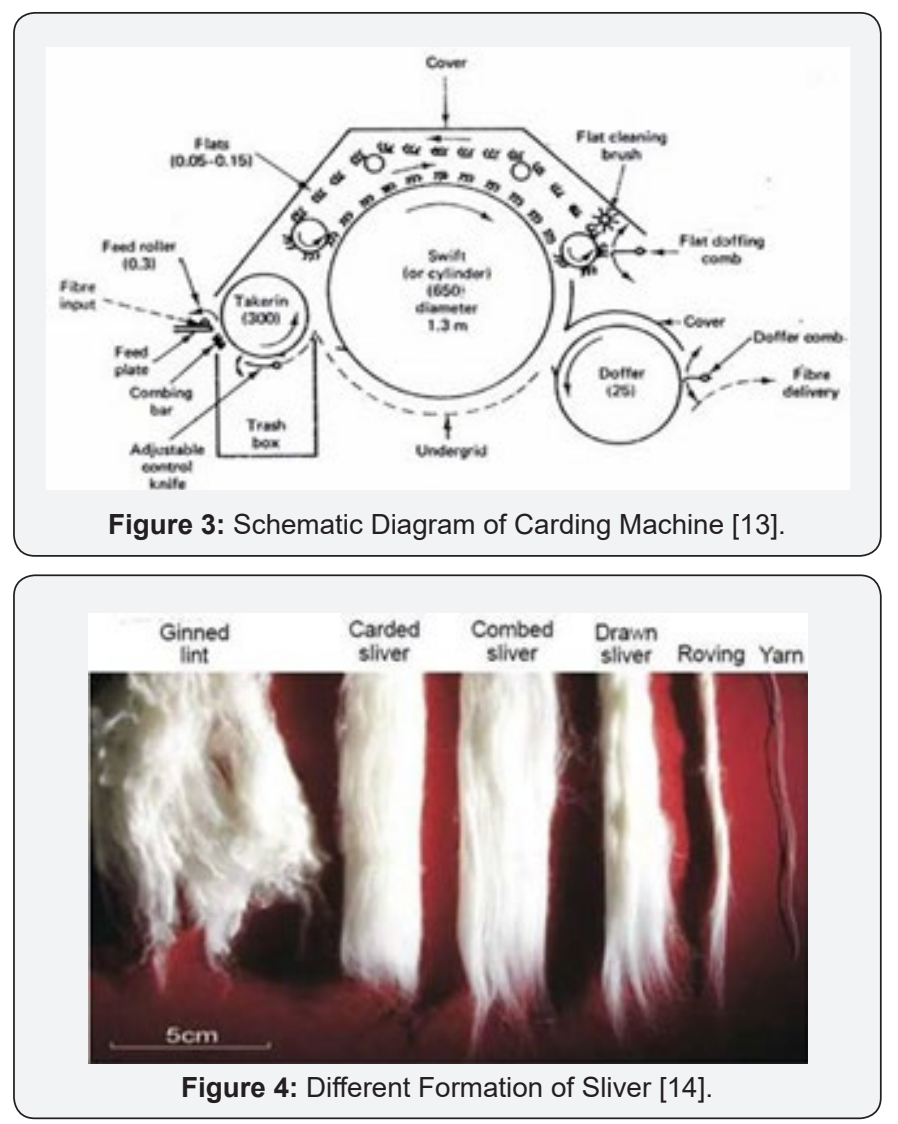

During carding, if it's needed to change draft then pinion normally changes. The number of the teeth of this changed DCP higher than draft will be less number. In the other hand, if number of teeth is less then draft will be higher (Figures 3 \& 4) [1]. Teruwaka Ogawa, Nori Matsumoto and Yukimatsu Miyamoto were studied that the draft of cotton spinning machines is affected by variations in temperature and relative humidity, and to fix a reasonable roll distance of the drafting element which will eliminate irregularity of draft [2]. Fumio Murakami, Toshio Shoman and Susumu Case studied that this is an attempt to approximate the characteristics of two major types of servo-draft systems the open-loop system and the closed-loop system by comparatively simple mathematical models consisting of linear transfer functions. The effectiveness of servo-draft systems in terms of the frequency response of the mathematical models has been investigated [3]. LPMT Laboratories de Physique et Mécanique Textiles, Mulhouse, Alsace FRANCE were studied that fiber surface properties have a significant effect on yarn spinning. The frictional behavior of fibers greatly influences their processing, their performance and the performance of the final product. In order to investigate the effect of fiber surface properties and inter-fiber friction during spinning process, card slivers are taken and subjected to three drawing passages. Card and drawing frame slivers are then tested by the Static Friction Tester (SFT), which has been developed earlier. Fiber fineness, maturity and fiber length are measured by using different testing instruments. Hook content is calculated by utilizing fiber length data. The statistical analysis of results shows the same trend for the different cotton fibers tested [4].
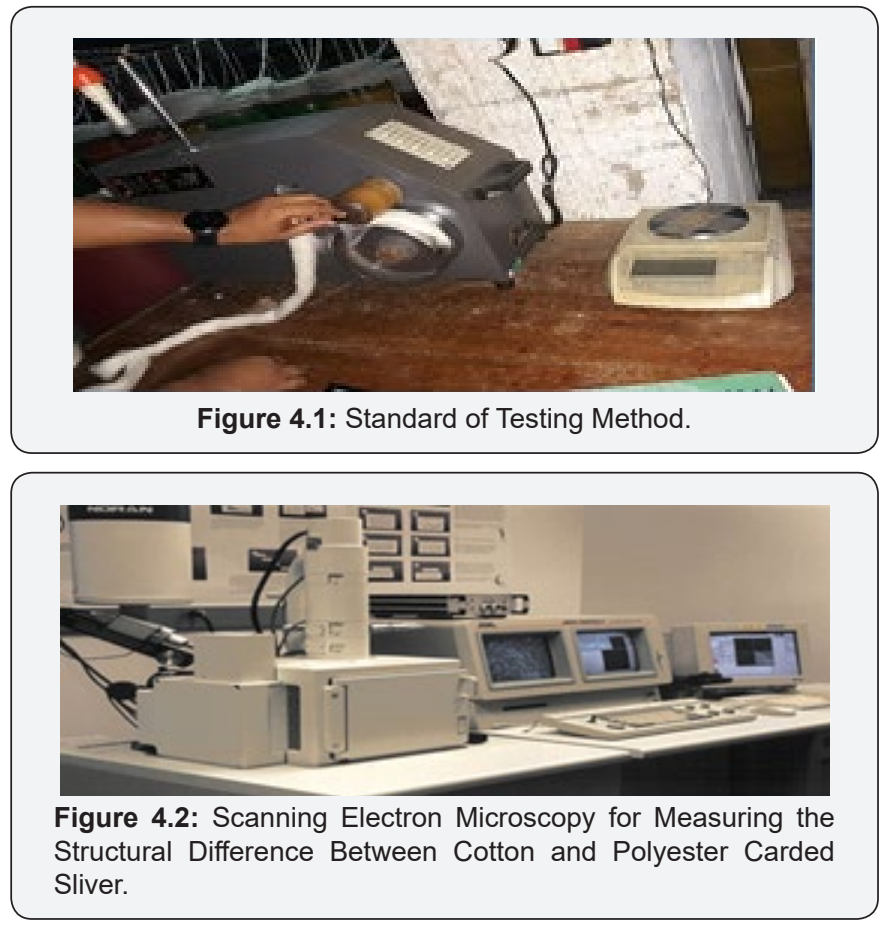

Yasemin Korkmaz was studied that the effects of fibre fineness on dynamic cohesion force at different delivery speeds for synthetic fibres. Sliver irregularity was positively correlated with variation in cohesion, while a negative correlation was detected between sliver irregularity and cohesion force and between sliver irregularity and fineness. Therefore, the slightest change in fibre fineness can cause dramatic changes in the drafting process and sliver irregularity. One of the most important parameters regarding the processability of a synthetic fibre is the 


\section{Current Trends in Fashion Technology \& Textile Engineering}

level of inter-fibre friction, which determines the drafting force or cohesive force dependent on such factors as surface conditions, crimping and lubricant deposit on the fibres. Staple length and crimp are highly significant factors affecting the cohesion values. Experiments conducted on cotton fibres revealed that there was a positive correlation between $2.5 \%$ span length and variation in cohesion force, which affected ends down in spinning. Fibres with smoother surfaces had greater cohesion than fibres with geometrically rough surfaces. Crimp drastically influences the cohesive force by changing the surface roughness and the crosssectional shape of fibres. Cohesive force and its influence on yarn quality, and their results indicated a strong interaction between the variability in drafting force and the variability in the single yarn strength. The inter-fibre friction affects the draft-in force which must be overcome in every drawing section of production.

Therefore, this force must be controlled in order to reduce any drafting problems. Although many studies have been conducted to determine the effect of fibre properties on drafting force, there is very little published information available on the effect of fibre fineness. In this study, the effect of fineness on the dynamic cohesion and its interaction with sliver irregularity were investigated [5]. Nasir Mahmood' \& Zahid Maqsood were studied that inadequate settings and inadequate feedings are the sources of variation in weight per yard of lap. Alan and Alexander (1988) pointed out that processing of fibres tends to produce neps through a stress build up/sudden release mechanism which induced buckling along the fibre length. Ali (1998) reported that calendar rolls pressure. kirschner beater gauges and kirschner beater speed mainly influenced the lap weight variation. He also recommended that $\mathrm{CV}$ of meter to meter lap weight be strictly controlled and maintained at level less than 2\%. Anonymous (1999) recommended that distance between stripping rail and the kirschner beater should be $2 \mathrm{~mm}$ [6]. D. R. Cox was studied that Sliver is drafted by passing it between two pairs of rollers moving with different speeds, a 'period' is produced in the thickness variations of the drafted sliver. The change in standard deviation of thickness is related to the properties of the sliver and of the drafting mechanism, and to the spectrum of the thickness of the initial sliver. One of the fundamental operations in the production of textile yarn from fibres is the process of drafting.

It consists in the drawing out of a thick intermediate web of fibres, or sliver, by one of two methods. In the first method, roller drafting, the sliver is passed between two pairs of rollers moving with different speeds, resulting in a reduction of thickness determined by the ratio of the roller speeds. The second method mule drafting, is an intermittent process in which successive lengths of sliver are gripped, extended and then wound on a bobbin [7]. Arindam Basua was studied that yarn structure and its relationship with the properties have attracted many researchers and scientists. This has resulted in many published research works scattered in many places. The importance of this subject has increased due to the need of yarn with best possible quality at optimum cost. Yarn can be defined as a product of substantial length and relatively small cross-section consisting of fibres and/ or filaments with or without twist [8]. Abdul Jabbar, Tanveer Hussain and Abdul Moqeet were studied that yarn unevenness increased by increasing card production rate and total yarn imperfections increased by decreasing card cylinder speed and increasing card production rate. Various processes involved in the spinning of carded spun yarn include cleaning and blending cotton in the blow room, carding, breaker and finisher drawing, roving formation on the simplex and yarn formation on the ring frame. The effect of different parameters of these processes on the resulting yarn quality, have been studied by various researchers in the past [9]. L.B. DeLuca, J. Simpson and L.A. Fiori were studied that the average drafting tenacity was directly related to the total amount of hooks present before drafting. A linear relationship exists between hooks in roving and hooks in the sliver fed to the roving frame [10].

Louis A. Fiori, John J. Brown and Jack E. Sands were studied that for cottons of comparable fiber length and weight fineness, the stronger fibered cotton produced the stronger 2-ply yarns. Also, differences in fiber strength do not affect twist-strength trends or percentage gain in strength of 2-ply over single yarns. The results of this study also indicate that fiber elongation is directly related to 2-ply yarn elongation [11]. D. D. McAlister, J. D. Bargeron and L. C. God bey were studied that fiber bundles in sliver form more closely represent the fiber bundles commonly used in commercial testing. Fiber quality, processing quality, and yarn quality were measured for each cotton in addition to finisher sliver drafting force where short fiber content has the greatest impact on drafting force. Determination of processing waste and spinning efficiency levels influences the determination of drafting force of sliver [12-14]. A.K.M. MAHABUBUZZAMAN, M.R. RASHID, F. AHMED, A.K. AZAD AND M.N. EHSAN were studied that the result of exemption parameters of the finisher card machine on the physical properties of all jute and jute-acrylic blended yarn. Carding is an important step in processing line of jute spinning. A cylinder is the heart of the whole carding machine due to the carding action, which causes from its cylinder speed and other rollers.

\section{Materials Used}

A medium grade cotton and polyester were used in this study. The cotton fibres and polyester were processed through a blow room and then blow room lap is applied in carding machine to observe the orientation of both fibre in same setting of carding machine. The properties of the cotton (Indian) which was used in the study like Length: $23.25 \mathrm{~mm}$, Fineness: $2.2 \mathrm{dtex}$, Tensile strength: 3.2 g/dtex, Color: Gray, Elasticity: Relatively low, Moisture Regain: 7.3\%. The properties of the polyester staple fiber (Indonesian) which was used in the study is as follows: Brand: Meije, Fineness: 3.5 dtex, Color: Raw white Grade: Recycled, Fiber length: $25 \mathrm{~mm}$ 


\section{Current Trends in Fashion Technology \& Textile Engineering}

\section{Machine used}

- $\quad$ Carding machine: TRUTZSCHLER (TC-03)

\section{Method:}

In this experiment, two $50 \mathrm{~kg}$ lap of cotton and polyester fibre was collected from blow room. The setting of carding machine was normal noted in carding machine parameter, only changed

\section{Testing}

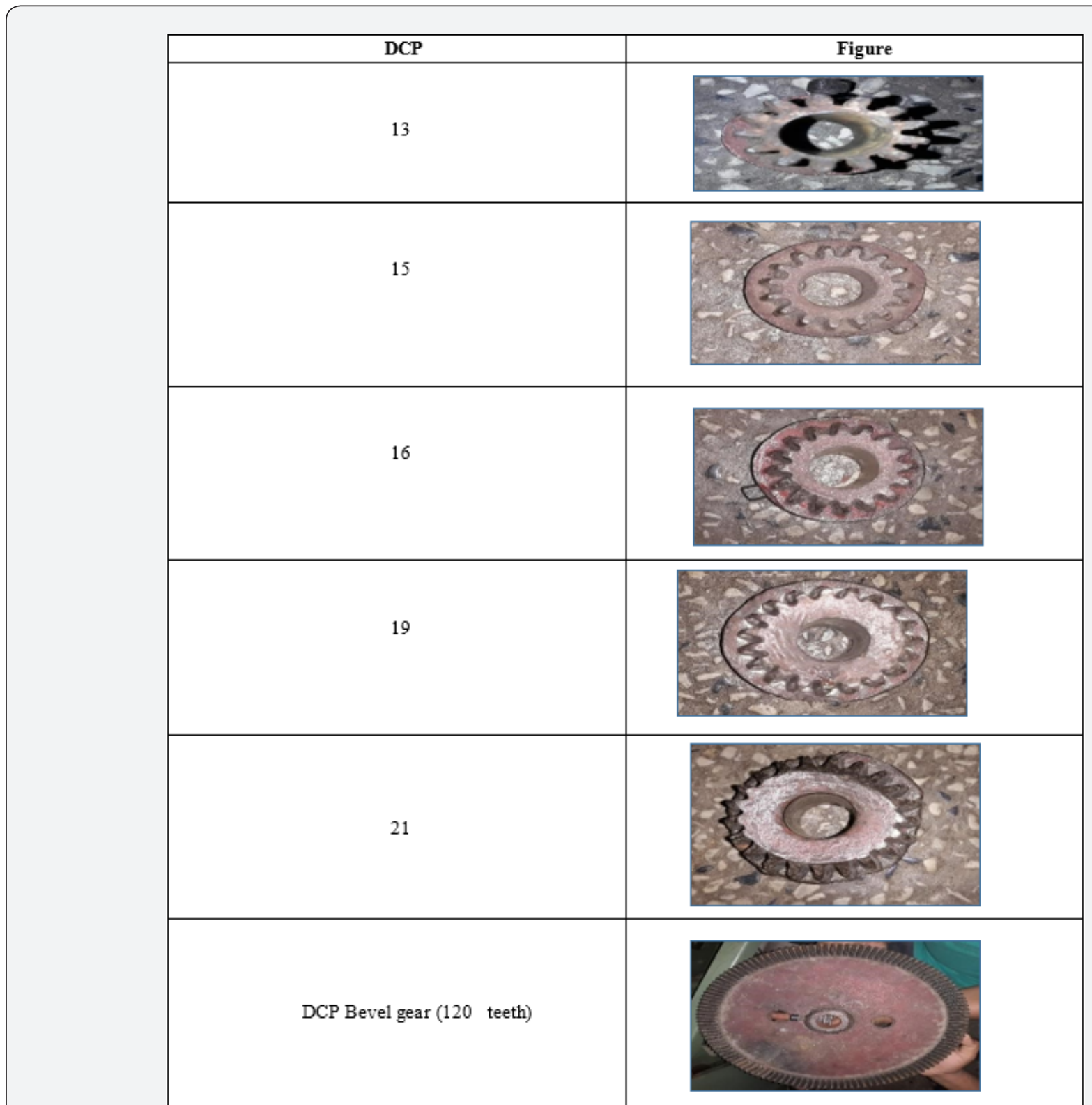

Figure 5: Different Types of Used DCP with DCP Bevel Gear.

Wrap block for sliver length measurement: Company: Mag, Origin, India, Standard of testing method: ISO 105-X13:2001 as well as electronic balance for sample weight measurement (Figures 4\&5) SEM (Scanning Electron Microscope) is a type of electron microscope that produces images of a sample by scanning the DCP. DCP-13 was set and run the machine as well as collected ten sample of more than 6yds sliver. As the same way, 6yds sample was collected for DCP-15, 17, 19, 21. The length of carded sample for ten different sample was measured with wrap block machine for DCP-13, 15, 17, 19, 21. All carded samples of 6yds were weighted with digital electronic balance and noted precisely. Temperature of production unit was maintained $42 \circ \mathrm{C}$ during the time of sample collection. 


\section{Current Trends in Fashion Technology \& Textile Engineering}

Table 1: Machine Setting Parameters During Experimentation.

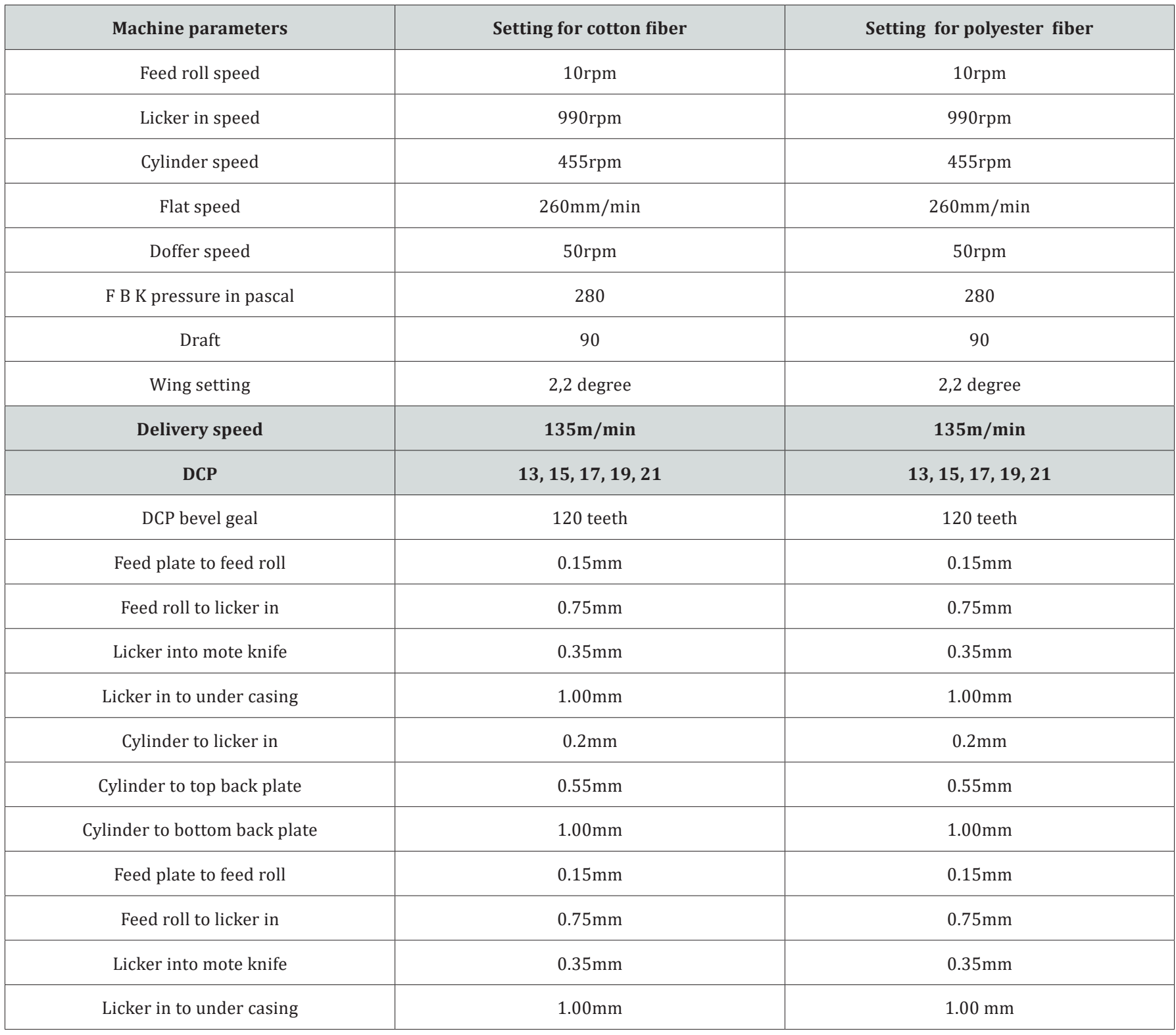

\section{Result and Discussion}

Table 2: Weight of Carded Sliver For (DCP 13).

\begin{tabular}{|c|c|c|}
\hline Sample No. & Cotton Sliver & Polyester sliver \\
\hline 1 & $15.17 \mathrm{gm} / 6 \mathrm{yds}$ & $14.15 \mathrm{gm} / 6 \mathrm{yds}$ \\
\hline 2 & $15.77 \mathrm{gm} / 6 \mathrm{yds}$ & $14.14 \mathrm{gm} / 6 \mathrm{yds}$ \\
\hline 3 & $15.35 \mathrm{gm} / 6 \mathrm{yds}$ & $13.65 \mathrm{gm} / 6 \mathrm{yds}$ \\
\hline 4 & $16.28 \mathrm{gm} / 6 \mathrm{yds}$ & $14.88 \mathrm{gm} / 6 \mathrm{yds}$ \\
\hline 5 & $15.27 \mathrm{gm} / 6 \mathrm{yds}$ & $13.29 \mathrm{gm} / 6 \mathrm{yds}$ \\
\hline 6 & $14.98 \mathrm{gm} / 6 \mathrm{yds}$ & $15.88 \mathrm{gm} / 6 \mathrm{yds}$ \\
\hline 7 & $15.63 \mathrm{gm} / 6 \mathrm{yds}$ & $14.03 \mathrm{gm} / 6 \mathrm{yds}$ \\
\hline 8 & $16.41 \mathrm{gm} / 6 \mathrm{yds}$ & $14.11 \mathrm{gm} / 6 \mathrm{yds}$ \\
\hline 9 & $16.80 \mathrm{gm} / 6 \mathrm{yds}$ & $14.89 \mathrm{gm} / 6 \mathrm{yds}$ \\
\hline 10 & $17.27 \mathrm{gm} / 6 \mathrm{yds}$ & $14.20 \mathrm{gm} / 6 \mathrm{yds}$ \\
\hline
\end{tabular}

Table 3: Weight of Carded Sliver for (DCP 15).

\begin{tabular}{|c|l|c|}
\hline Sample No. & Cotton Sliver & Polyester sliver \\
\hline 1 & $19.78 \mathrm{gm} / 6 \mathrm{yds}$ & $18.98 \mathrm{gm} / 6 \mathrm{yds}$ \\
\hline 2 & $20.14 \mathrm{gm} / 6 \mathrm{yds}$ & $18.12 \mathrm{gm} / 6 \mathrm{yds}$ \\
\hline 3 & $18.73 \mathrm{gm} / 6 \mathrm{yds}$ & $17.33 \mathrm{gm} / 6 \mathrm{yds}$ \\
\hline 4 & $19.15 \mathrm{gm} / 6 \mathrm{yds}$ & $18.10 \mathrm{gm} / 6 \mathrm{yds}$ \\
\hline 5 & $20.35 \mathrm{gm} / 6 \mathrm{yds}$ & $18.30 \mathrm{gm} / 6 \mathrm{yds}$ \\
\hline 6 & $20.15 \mathrm{gm} / 6 \mathrm{yds}$ & $19.55 \mathrm{gm} / 6 \mathrm{yds}$ \\
\hline 7 & $19.16 \mathrm{gm} / 6 \mathrm{yds}$ & $19.06 \mathrm{gm} / 6 \mathrm{yds}$ \\
\hline 8 & $19.39 \mathrm{gm} / 6 \mathrm{yds}$ & $19.39 \mathrm{gm} / 6 \mathrm{yds}$ \\
\hline 9 & $18.85 \mathrm{gm} / 6 \mathrm{yds}$ & $18.00 \mathrm{gm} / 6 \mathrm{yds}$ \\
\hline 10 & $18.14 \mathrm{gm} / 6 \mathrm{yds}$ & $17.64 \mathrm{gm} / 6 \mathrm{yds}$ \\
\hline
\end{tabular}




\section{Current Trends in Fashion Technology \& Textile Engineering}

Table 4: Weight of Carded Sliver for (DCP 17)

\begin{tabular}{|c|c|c|}
\hline Sample No. & Cotton Sliver & Polyester sliver \\
\hline 1 & $21.08 \mathrm{gm} / 6 \mathrm{yds}$ & $19.88 \mathrm{gm} / 6 \mathrm{yds}$ \\
\hline 2 & $20.30 \mathrm{gm} / 6 \mathrm{yds}$ & $19.30 \mathrm{gm} / 6 \mathrm{yds}$ \\
\hline 3 & $20.12 \mathrm{gm} / 6 \mathrm{yds}$ & $18.22 \mathrm{gm} / 6 \mathrm{yds}$ \\
\hline 4 & $20.68 \mathrm{gm} / 6 \mathrm{yds}$ & $18.78 \mathrm{gm} / 6 \mathrm{yds}$ \\
\hline 5 & $20.05 \mathrm{gm} / 6 \mathrm{yds}$ & $19.05 \mathrm{gm} / 6 \mathrm{yds}$ \\
\hline 6 & $20.91 \mathrm{gm} / 6 \mathrm{yds}$ & $19.99 \mathrm{gm} / 6 \mathrm{yds}$ \\
\hline 7 & $20.10 \mathrm{gm} / 6 \mathrm{yds}$ & $19.15 \mathrm{gm} / 6 \mathrm{yds}$ \\
\hline 8 & $20.27 \mathrm{gm} / 6 \mathrm{yds}$ & $19.27 \mathrm{gm} / 6 \mathrm{yds}$ \\
\hline 9 & $20.25 \mathrm{gm} / 6 \mathrm{yds}$ & $19.25 \mathrm{gm} / 6 \mathrm{yds}$ \\
\hline 10 & $20.52 \mathrm{gm} / 6 \mathrm{yds}$ & $19.02 \mathrm{gm} / 6 \mathrm{yds}$ \\
\hline
\end{tabular}

Table 5: Weight of Carded Sliver for (DCP 19).

\begin{tabular}{|c|c|c|}
\hline Sample No. & Cotton Sliver & Polyester sliver \\
\hline 1 & $24.05 \mathrm{gm} / 6 \mathrm{yds}$ & $23.88 \mathrm{gm} / 6 \mathrm{yds}$ \\
\hline 2 & $25.16 \mathrm{gm} / 6 \mathrm{yds}$ & $24.30 \mathrm{gm} / 6 \mathrm{yds}$ \\
\hline 3 & $24.23 \mathrm{gm} / 6 \mathrm{yds}$ & $23.22 \mathrm{gm} / 6 \mathrm{yds}$ \\
\hline 4 & $25.11 \mathrm{gm} / 6 \mathrm{yds}$ & $24.78 \mathrm{gm} / 6 \mathrm{yds}$ \\
\hline 5 & $24.35 \mathrm{gm} / 6 \mathrm{yds}$ & $23.05 \mathrm{gm} / 6 \mathrm{yds}$ \\
\hline 6 & $25.38 \mathrm{gm} / 6 \mathrm{yds}$ & $23.99 \mathrm{gm} / 6 \mathrm{yds}$ \\
\hline 7 & $24.90 \mathrm{gm} / 6 \mathrm{yds}$ & $23.15 \mathrm{gm} / 6 \mathrm{yds}$ \\
\hline 8 & $25.40 \mathrm{gm} / 6 \mathrm{yds}$ & $23.27 \mathrm{gm} / 6 \mathrm{yds}$ \\
\hline 9 & $24.93 \mathrm{gm} / 6 \mathrm{yds}$ & $23.25 \mathrm{gm} / 6 \mathrm{yds}$ \\
\hline 10 & $24.90 \mathrm{gm} / 6 \mathrm{yds}$ & $23.02 \mathrm{gm} / 6 \mathrm{yds}$ \\
\hline
\end{tabular}

Table 6: Weight of Carded Sliver for (DCP 21).

\begin{tabular}{|c|c|c|}
\hline Sample No. & Cotton Sliver & Polyester sliver \\
\hline 1 & $27.30 \mathrm{gm} / 6 \mathrm{yds}$ & $25.10 \mathrm{gm} / 6 \mathrm{yds}$ \\
\hline 2 & $27.78 \mathrm{gm} / 6 \mathrm{yds}$ & $26.78 \mathrm{gm} / 6 \mathrm{yds}$ \\
\hline 3 & $25.95 \mathrm{gm} / 6 \mathrm{yds}$ & $24.22 \mathrm{gm} / 6 \mathrm{yds}$ \\
\hline 4 & $26.25 \mathrm{gm} / 6 \mathrm{yds}$ & $24.25 \mathrm{gm} / 6 \mathrm{yds}$ \\
\hline 5 & $26.33 \mathrm{gm} / 6 \mathrm{yds}$ & $25.30 \mathrm{gm} / 6 \mathrm{yds}$ \\
\hline 6 & $25.50 \mathrm{gm} / 6 \mathrm{yds}$ & $23.70 \mathrm{gm} / 6 \mathrm{yds}$ \\
\hline 7 & $24.80 \mathrm{gm} / 6 \mathrm{yds}$ & $23.85 \mathrm{gm} / 6 \mathrm{yds}$ \\
\hline 8 & $28.57 \mathrm{gm} / 6 \mathrm{yds}$ & $27.77 \mathrm{gm} / 6 \mathrm{yds}$ \\
\hline 9 & $26.92 \mathrm{gm} / 6 \mathrm{yds}$ & $25.22 \mathrm{gm} / 6 \mathrm{yds}$ \\
\hline 10 & $26.62 \mathrm{gm} / 6 \mathrm{yds}$ & $25.32 \mathrm{gm} / 6 \mathrm{yds}$ \\
\hline
\end{tabular}

Weight variation of cotton and polyester carded sliver in different Draft Change Pinion (DCP): (Tables 2-7) (Figures 6-11). The weight of the sliver is almost nearest for all DCP due to having same machine parameters of carding machine, but highly smoother/less weight variation was found for DCP-17. The overall weight variation in cotton and polyester sliver/6yds is considered in general as DCP-13<DCP-15<DCP-17<DCP-19<DCP-21. Cotton sliver weight in gm/6yds showed almost (4-10) \% less comparing to polyester sliver for different DCP.
Table 7: Average Weight of Cotton and Polyester Sliver.

\begin{tabular}{|c|c|c|c|}
\hline $\begin{array}{c}\text { DCP (Draft } \\
\text { Change } \\
\text { Pinion) }\end{array}$ & $\begin{array}{c}\text { Cotton } \\
\text { Sliver in } \\
\text { gm/6yds }\end{array}$ & $\begin{array}{c}\text { Polyester } \\
\text { Sliver in } \\
\text { gm/6yds }\end{array}$ & $\begin{array}{c}\text { Difference Between } \\
\text { Polyester and Cotton } \\
\text { Sliver in gm/6yds }\end{array}$ \\
\hline 13 & 15.9 & 14.32 & $9.93 \%$ \\
\hline 15 & 19.38 & 18.45 & $4.80 \%$ \\
\hline 17 & 20.42 & 19.11 & $6.41 \%$ \\
\hline 19 & 24.85 & 23.6 & $5.83 \%$ \\
\hline 21 & 26.6 & 25.13 & $5.52 \%$ \\
\hline
\end{tabular}

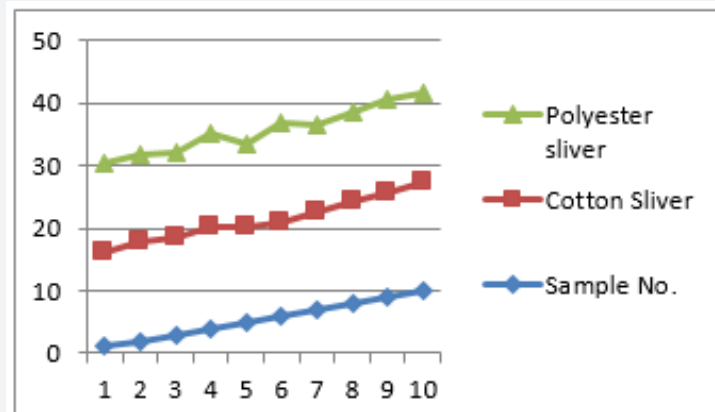

Graphical Representation of Weight Variation Between Cotton and Carded Sliver.

Figure 6: Weight Variation of Cotton and Polyester Carded Sliver in Draft Change Pinion-13 for 10 Different Sample.

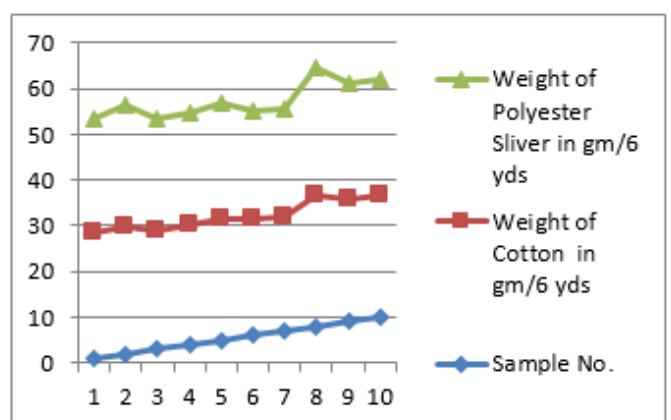

Figure 7: Weight Variation of Cotton and Polyester Carded Sliver in Draft Change Pinion-15 For 10 Different Sample.

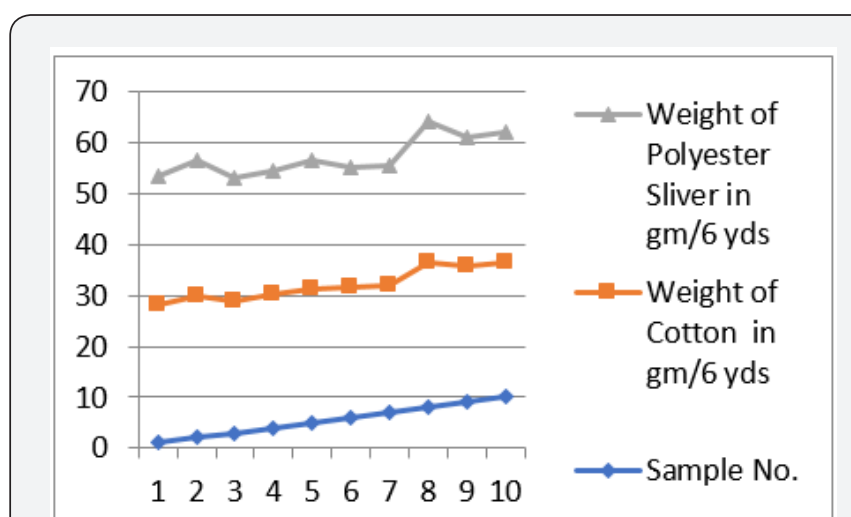

Figure 8: Weight Variation of Cotton and Polyester Carded Sliver in Draft Change Pinion-17 for 10 Different Sample. 


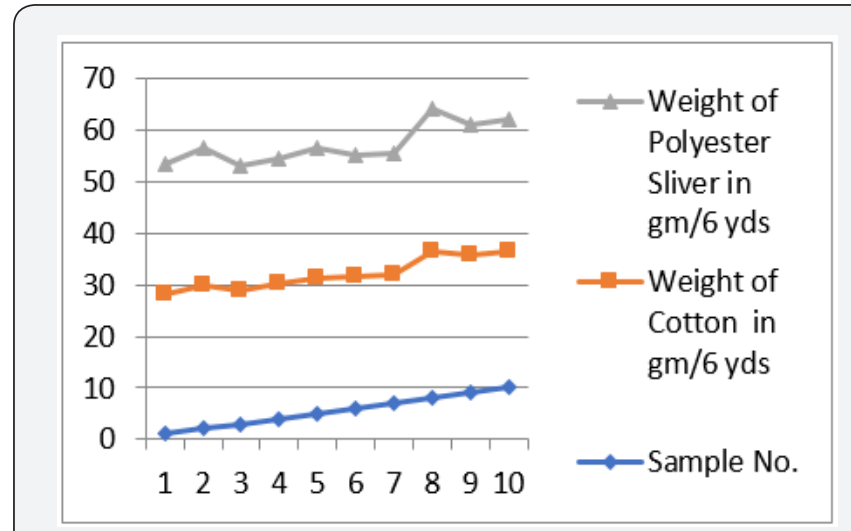

Figure 9: Weight Variation of Cotton and Polyester Carded Sliver in Draft Change Pinion-19 for 10 Different Sample.

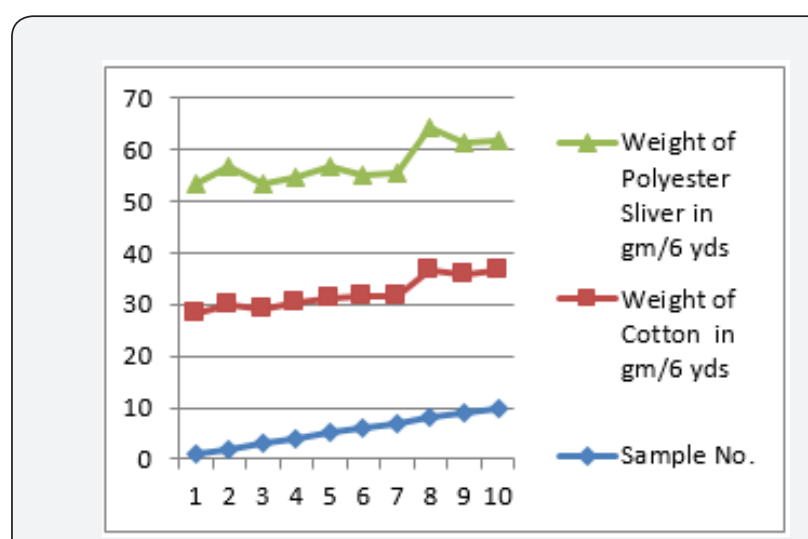

Figure 10: Weight Variation of Cotton and Polyester Carded Sliver in Draft Change Pinion-21 for 10 Different Sample.

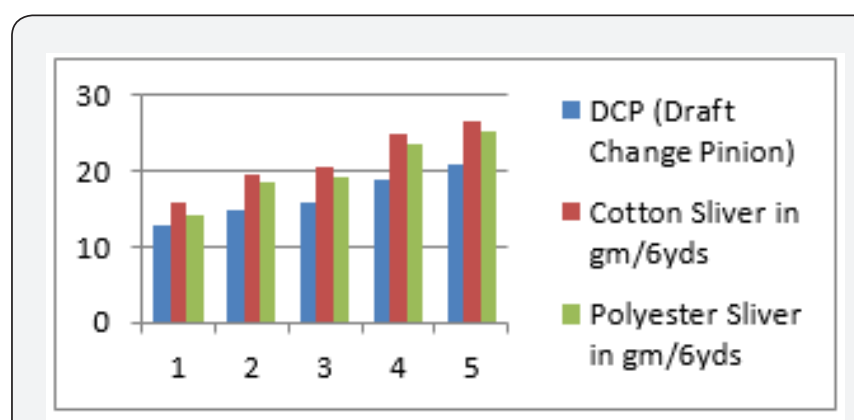

Figure 11: Average Weight Variation of Cotton and Polyester Carded Sliver for Different DCP.

[1=DCP 13, 2= DCP 15, 3= DCP 17, 4= DCP 19, 5= DCP 21].

\section{SEM Study of Cotton and Polyester Carded Sliver for Draft Change Pinion 17:}

SEM Study of Cotton and Polyester Carded Sliver for Draft Change Pinion 17 was observed due to having less fluctuation of weight and its orientation was analyzed for observation of sliver surface variation. Scanning Electron Microscope (SEM) analysis for cotton carded sliver and polyester carded sliver with $30 \mathrm{KV} \mathrm{VP-}$ SEM showed an orientation of cotton and polyester carded sliver. For $20 \mu \mathrm{m}$ cotton carded sliver, the lengthwise value of Electron High Tension (EHT) is $5.00 \mathrm{KV}$, Working Distance (WD) between the sample and low portion of the lens is $8.5 \mathrm{~mm}$, Magnification (Mag) is $1.00 \mathrm{~K} \mathrm{X}$ and signal A is Secondary Electron (SE1). For $2 \mu \mathrm{m}$ cotton carded sliver, the widthwise value of Electron High Tension (EHT) is $5.00 \mathrm{kV}$, Working Distance (WD) between the sample and low portion of the lens is $8.5 \mathrm{~mm}$, Magnification (Mag) is $5.00 \mathrm{~K}$ $\mathrm{X}$ and signal A is Secondary Electron (SE1) (Figures 12\&13). For $10 \mu \mathrm{m}$ polyester carded sliver, the lengthwise value of Electron High Tension (EHT) is $5.00 \mathrm{kV}$, Working Distance (WD) between the sample and low portion of the lens is $9.00 \mathrm{~mm}$, Magnification (Mag) is $1.00 \mathrm{~K} \mathrm{X}$ and signal A is Secondary Electron (SE1). For 2 $\mu \mathrm{m}$ polyester carded sliver, the widthwise value of Electron High Tension (EHT) is 5.00KV. SEM study of polyester and cotton sliver were investigated the effect of fineness for different cohesion of natural fibre as cotton and synthetic fibre as polyester and its interaction with sliver irregularity, surface variation when it was trialed with Draft Change Pinion-17. SEM testing of cotton carded sliver and polyester carded sliver with $30 \mathrm{KV}$ VP-SEM had been tested in Bangladesh Council of Scientific and Industrial Research (BCSIR).

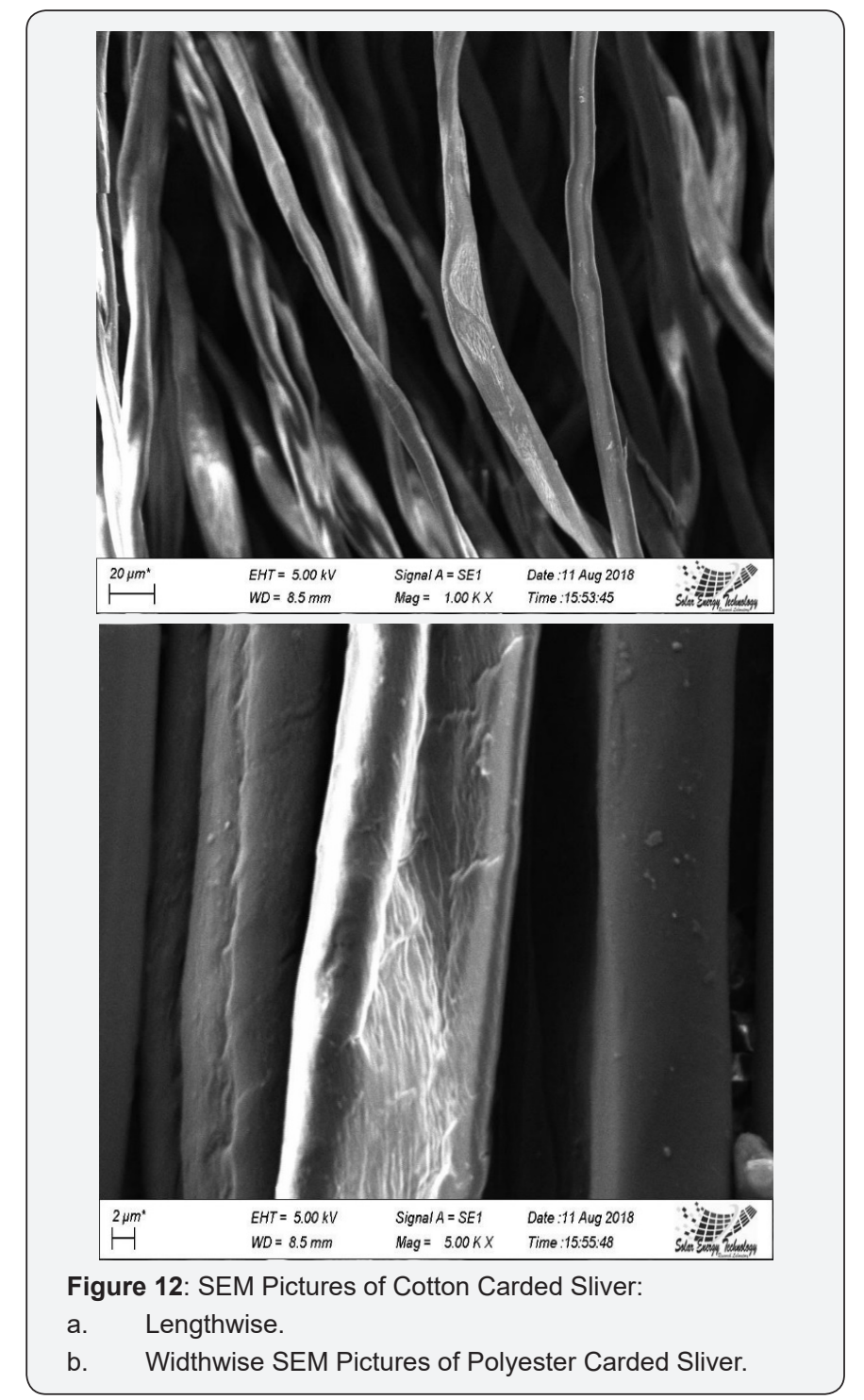




\section{Current Trends in Fashion Technology \& Textile Engineering}
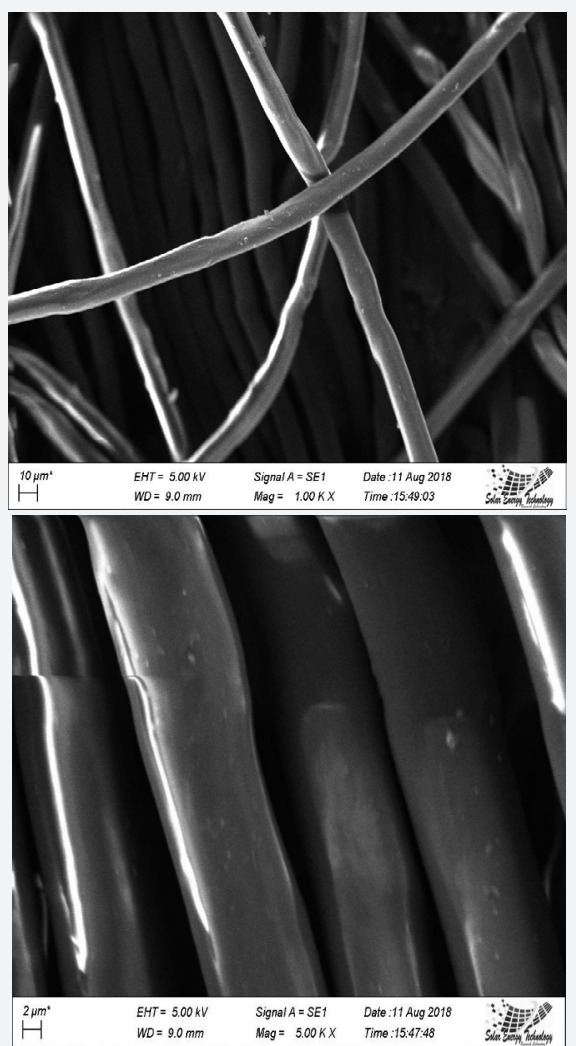

Figure 13: SEM Pictures Of Polyester Carded Sliver:

a. Lengthwise

b. Widthwise.

The Scanning Electron Microscope (SEM) shows the evidence of sliver debonding, sliver split, sliver slicing, matrix damage and weak fiber-matrix interfacial bonds. More aggregation and impurities of fibre showed in cotton card than polyester card. Cotton card sliver surface showed geometrically rough than the surface of polyester card sliver which indicates that Fibres with smoother surfaces had greater cohesion than fibres with geometrically rough surfaces.

\section{Conclusion}

So, an optimum selection of DCP may confirm the orientation of fibre in carding stage as well as ensuring the quality of finished yarn for cotton spinning and polyester-cotton blended. Sliver irregularity was positively correlated with variation in cohesion, while a negative correlation was detected between sliver irregularity and cohesion force and between sliver irregularity and fineness. Therefore, the slightest change in fibre fineness can cause dramatic changes in the drafting process. Fiber properties, card setting, and the performance of card sliver are greatly affected by the frictional behavior of the fiber assemblies for both cotton and polyester fibre. Fibre hooks in sliver can be minimized by setting proper DCP in carding which may eliminate yarn hairiness.

\section{References}

1. Teruwaka Ogawa, Nori Matsumoto, Yukimatsu Miyamoto (2014) A Study on Sliver Strength and Draft Efficiency. Kanegafuchi Spinning Co., Ltd.

2. Fumio Murakami, Toshio Shoman, Susumu Kase (2016) Continuous Control of Sliver Thickness. Toyo Spinning, Osaka, Japan.

3. Sheraz Ahmad, Artan Sinoimeri, Shahram Nowrouzieh (2012) The Effect of the Sliver Fiber Configuration on the Cotton Inter-fiber Frictional Forces. LPMT Laboratoire de Physique etMécanique Textiles, Mulhouse, Alsace FRANCE. Cotton Research Institute of Iran, Gorgan, IRAN,Journal of Engineered Fibers and Fabrics 7(2): 87-93.

4. Yasemin Korkmaz, Kahramanmaraş Sütçü (2004) İmam University Faculty of Engineering, Department of Textile Engineering Kahramanmaraș, Turkey. Fibre and textile in Eastern Europe January / March 12: 1.

5. Nasir Mahmood, Zahid Maqsood (2002) Department of Fibre Technology, University of Agriculture, Faisalabad and 2ASM Zainab Textile Mills Ltd, Faisalabad. Pak J Agri Sci 39: 1.

6. Cox DR (1949) Theory of Drafting of Wool Slivers, Proceedings of the Royal Society of London. Series A, Mathematical and Physical Sciences 197: 28-51.

7. Arindam Basu (2009) Yarn structure - properties relationship. The South India Textile Research Association, Coimbatore 641 014, India, Indian Journal of Fibre \& Textile Research 34: 287-294

8. Abdul Jabbar, Tanveer Hussain, Abdul Moqeet (2013) Impact of Carding Parameters and Draw Frame Doubling on the Properties of Ring Spun Yarn. National Textile University, Faisalabad, Punjab PAKISTAN Journal of Engineered Fibers and Fabrics 8(2): 1-7.

9. DeLuca LB, Simpson j, Fiori LA (1968) An Evaluation of Fiber Parallelization and Drafting Tenacity of Cotton Sliver. Southern Regional Research Laboratory, New Orleans, Louisiana 70119, USA 38(8): 817823.

10. Louis A Fiori, John J Brown, Jack E Sands (1956) The Effect of Cotton Fiber Strength on the Properties of 2-Ply Carded Yarns. Southern Regional Research Laboratory, New Orleans, Louisiana 26(4): 296-302.

11. McAlister DD, Bargeron JD, III, Godbey LC (2003) Using cotton sliver draft force to evaluate textile processing efficiency, Part I. Applied Engineering in Agriculture, American Society of Agricultural Engineers 19(6): 637-640.

12. Mahabubuzzaman AKM, Rashid MR, Ahmed F, Azad AK, Ehsan MN (2012) Analysis on the result of exemption parameters of the finisher card machine on the physical properties of all jute and jute acrylic blended yarn. An International Scientific Research Publisher Toronto, Canada 2(1): 21-24.

13. https://smediacacheak0.pinimg.com/736x/46/1b/85/461b85a7e1d67889263898ad6546a527.jpg

14. https://tse2.mm.bing.net/th?id=0IP.4SWIZIAMoZPINCjrHmOnA$\mathrm{HaFj} \&$ pid $=\mathrm{Api} \& \mathrm{P}=0 \& \mathrm{w}=230 \& \mathrm{~h}=173$. 
Your next submission with Juniper Publishers will reach you the below assets

- Quality Editorial service

- Swift Peer Review

- Reprints availability

- E-prints Service

- Manuscript Podcast for convenient understanding

- Global attainment for your research

- Manuscript accessibility in different formats ( Pdf, E-pub, Full Text, Audio)

- Unceasing customer service

Track the below URL for one-step submission https://juniperpublishers.com/online-submission.php 